\title{
Comparison of Pigtail with J Anchor Bolt in Normal Concrete
}

\author{
Mohamad Hairi Osman ${ }^{1, *}$, Mohamad Nur Mustaqim Abd Shukor ${ }^{1}$, Suraya Hani Adnan ${ }^{1}$, Mohamad Luthfi Ahmad \\ Jeni $^{1}$, Mohd Sufyan Abdullah ${ }^{1}$, Salman Salim², Hannifah Tami ${ }^{3}$, and Nor Azira Abdul Rahman ${ }^{4}$ \\ ${ }^{1}$ Faculty of Engineering Technology, Universiti Tun Hussein Onn Malaysia, Parit Raja, Batu Pahat, Johor, Malaysia \\ ${ }^{2}$ Centre For Diploma Studies, Universiti Tun Hussein Onn Malaysia, Parit Raja, Batu Pahat, Johor, Malaysia \\ ${ }^{3}$ Faculty of Civil and Environmental Engineering, Universiti Tun Hussein Onn Malaysia, Parit Raja, Batu Pahat, Johor, Malaysia \\ ${ }^{4}$ Politeknik Sultan Abdul Halim Mu'adzam Shah, Bandar Darulaman, Jitra, Kedah Darul Aman, Malaysia
}

\begin{abstract}
Anchor bolts have been used to attach the steel structure of concrete and transfer load into the concrete. Anchor bolts in concrete are to withstand the shear force as they connect steel beams to the reinforced concrete foundations. The research was carried out to increase the understanding and investigating the performance of anchor bolts Pigtail since there is a lack of research on the bolt and to compare it with anchor bolts $J$ which have been widely used by the industry. According to the methodology, testing the tensile load was used in this research to get a maximum load capacity of the anchor bolt in concrete. The sample was embedded in concrete cylinders of $75 \mathrm{~mm}$ radius and $300 \mathrm{~mm}$ height. Depths of embedment were $200 \mathrm{~mm}, 230 \mathrm{~mm}$, and $260 \mathrm{~mm}$. The Universal Testing Machine, UTM was used to test the strength of tensile. 12 samples were used, each type and depth used two samples to get the average value using concrete grade 30 . The samples underwent the process of curing for 28 days. The anchor bolts $\mathrm{J}$ used a $40 \mathrm{~mm}$ bending radius and the length of hook was $100 \mathrm{~mm}$. Anchor bolts pigtail also used the 10 bending radius with depth of $8 \mathrm{~mm}$ that have been compressed using $16 \mathrm{~mm}$ radius rigs with a load of $500 \mathrm{kN}$. Results of the research showed the depth of $260 \mathrm{~mm}$ for Pigtail almost the same with $\mathrm{J} 60.529 \mathrm{kN}$ and $53.628 \mathrm{kN}$ and anchor bolts $\mathrm{J}$ were $75.557 \mathrm{kN}$ and $76.332 \mathrm{kN}$. Difference of the values was not too far vary when compared with the $200 \mathrm{~mm}$ and $230 \mathrm{~mm}$ depths. Each comparison showed the ability of each bolt and anchor bolt failure occurred. Performance of the anchor bolts pigtail can be used on a structure or a higher load at an embedment of $260 \mathrm{~mm}$. Embedment of $200 \mathrm{~mm}$ and $230 \mathrm{~mm}$ can be used on a lighter load if steel material saving is a priority in every usage.
\end{abstract}

\section{Introduction}

$\mathrm{J}$ anchor bolt has been widely used for construction industry today. However, Pigtail anchor bolts had less exposure and use in the construction industry. Normally Pigtails anchor bolts were used as a connection between the structures. The problem which always occurred is that $\mathrm{J}$ anchor bolt is difficult to install in the reinforcement bar due to its shape. Furthermore, lack of research has been done to prove that Pigtail anchor bolts may be used as the same function as $\mathrm{J}$ anchor bolts.

The objective of this research is to investigate the performance of Pigtail and $\mathrm{J}$ anchor bolts embedded in normal concrete under tensile load test. Next objective is to find out the optimum of embedment and investigate the type of failure that occurs until maximum load is achieved.

\subsection{Scope of study}

In this study, all the tests were using Universal Testing Machine (UTM). This research used two types of bolt systems which were Pigtail and $\mathrm{J}$ anchor bolts. The tests were limited to tensile load only for Pigtail and $\mathbf{J}$ as the anchor bolt in concrete. The embedment length of anchor bolts samples J1A, J2A, P1A and P2A in the concrete was $200 \mathrm{~mm}$. Next samples, J1B, J2B, P1B and P2B were $230 \mathrm{~mm}$ embedded in the concrete. Next samples, J1C, J2C, P1C and P2C were embedded $260 \mathrm{~mm}$ in the concrete. All samples were using the same dimensions of concrete cylinders which were $75 \mathrm{~mm}$ in radius and $300 \mathrm{~mm}$ in height. These concrete were going through the curing process of 28 days. Concrete plate was supported by a platform with dimensions of $150 \mathrm{~mm}$ x $150 \mathrm{~mm} \times 300 \mathrm{~mm}$ when tested using the UTM. The plate design platform and anchor bolt tensile capacity were based on BS 5950-1: 2000.

\section{$1.2 \mathrm{~J}$ anchor bolt, $\mathrm{L}$ anchor bolt and pigtail anchor bolt}

Bolt anchors $\mathrm{J}$ and $\mathrm{L}$ are always used in the constructions. $180^{\circ}$ and $90^{\circ}$ bending by the end of each of the components aim to transfer load from upper structure to the lower structure. The anchor positions

\footnotetext{
*Corresponding author: mhairi@uthm.edu.my
} 
must be coordinated with the reinforcement due to large constructions area and making it easy for installation at the construction site so that errors can be reduced [15]. A common problem during site installation there is. This is a critical job and is often done by skilled labour [6]. After that, it is not guaranteed that we can use after the installation is done because in the process of hardening the concrete, there is a possibility of movement or vibration in the anchor bolts in which to anchor the resulting movement. If bolt size or design does not follow the specifications after the concrete is harden, it needs to be re-issued in order to replace with the new anchor bolt [14]. Several types of anchors Cast-in-place are hex headed, L-bolt, J-bolt and bolt Welded headed (see Fig.1) [9]

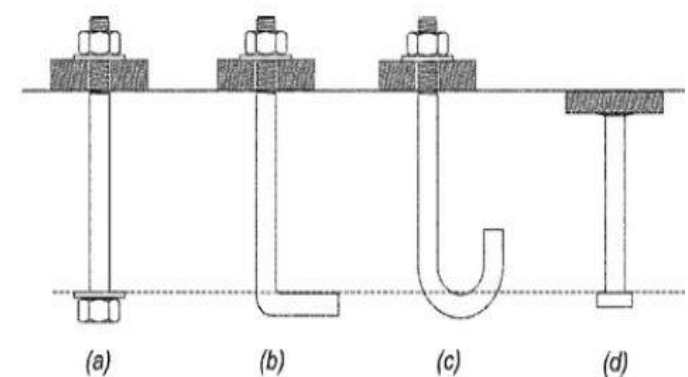

Fig. 1. a) Hex headed bolt b) L-bolt c) J-bolt d) Welded headed bolt

Pigtail anchor is with 10 bends in the concrete. Pigtail anchor bolt has a unique design, which gradually increases the depth of each groove to increase the length of the flexible anchor. The front of the anchor line allows transferring the pressure on the entire length. The gradient is positive that anchors are in high friction with the bend on the anchor (see Fig 2) [21]

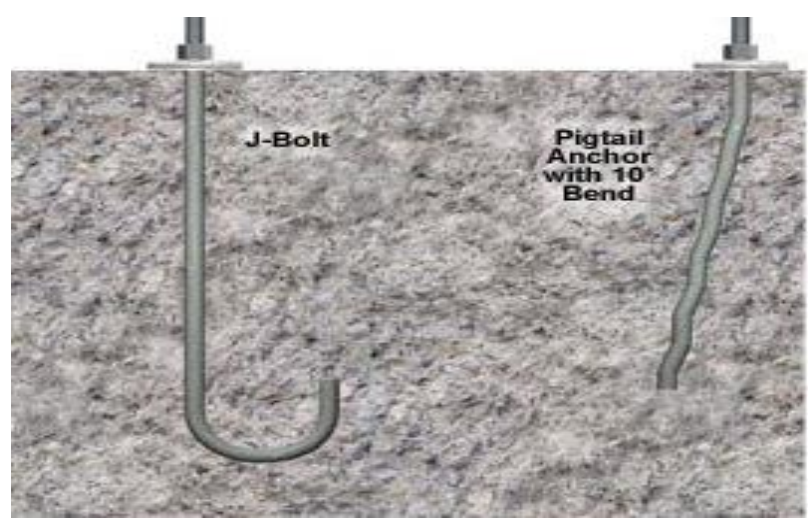

Fig. 2. Anchor bolt of $\mathrm{J}$ and pigtail

\section{Experimental Work}

Tensile strength test has been used in this experiment to obtain the capacity of load for the anchor bolts.

\subsection{Samples Preparation}

Pigtail Anchor bolts were made of reinforcement bar Y12. The diameters of the bolts were $12 \mathrm{~mm}$ or $16 \mathrm{~mm} \mathrm{[3,}$ 11]. Preparation of the pigtail anchor bolts using a compression machine to form bending was as shown in Fig.3. The reinforcement bar Y12 was placed between the reinforcement rigs to be compressed with $500 \mathrm{KN}$. The rig was made of $16 \mathrm{~mm}$ diameter bars which were $16 \mathrm{~mm}$ bars between each bending. Bonding connections on the rig had been ensured to have no movement or failure during compression. Fig. 4 shows the rig and pigtail anchor bolt formed after the compression was completed.

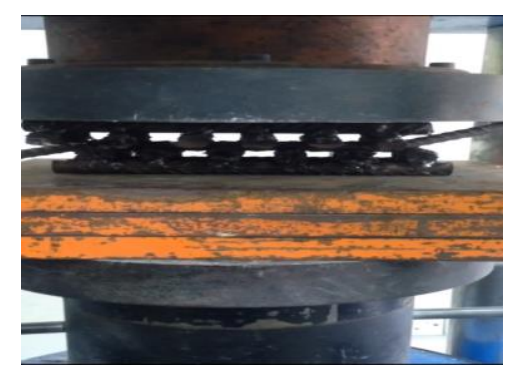

Fig. 3. Compression on bar

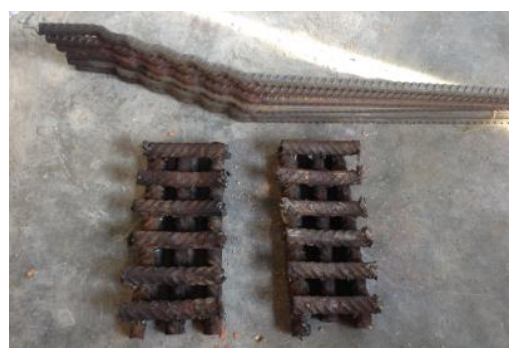

Fig. 4. Anchor bolt Pigtail and rig

Samples of the pigtail anchor bolts which have 10 bending with $16 \mathrm{~mm}$ of diameter and also the distance at the end of pigtail anchor bolts from the original position was $50 \mathrm{~mm}$. All samples were following the same distance to avoid the negative impact on the results. The radius of the $\mathrm{J}$ hook or curve of each sample was $40 \mathrm{~mm}$ and the length of the hook to the $\mathrm{J}$ anchor bolt all designed with $100 \mathrm{~mm}$ in each anchor bolt and was set to the same length [3]. Table 1 shows the embedment of anchor bolts which have been used in this research. The symbol of $\mathrm{J}$ is for $\mathrm{J}$-Bolt and $\mathrm{P}$ is for Pigtail. Symbol A, B and C is for depth 200, 230 and 260mm. Symbol 1 and 2 to show sample 1 and 2 . 
Table 1. Embedment J and Pigtail.

\begin{tabular}{|c|c|c|c|c|c|c|c|}
\hline \multirow{2}{*}{ Sample } & \multicolumn{3}{|c|}{$\begin{array}{c}\text { Embedment } \\
\text { Depth (mm) }\end{array}$} & \multirow{2}{*}{ Sample } & \multicolumn{4}{c|}{$\begin{array}{c}\text { Embedment } \\
\text { Depth(mm) }\end{array}$} \\
\cline { 2 - 5 } & 200 & 230 & 260 & & 200 & 230 & 260 \\
\hline J1A & $\sqrt{ }$ & & & P1A & $\sqrt{ }$ & & \\
\hline J2A & $\sqrt{ }$ & & & P2A & $\sqrt{ }$ & & \\
\hline J1B & & $\sqrt{ }$ & & P1B & & $\sqrt{ }$ & \\
\hline J2B & & $\sqrt{ }$ & & P2B & & $\sqrt{ }$ & \\
\hline J1C & & & $\sqrt{ }$ & P1C & & & $\sqrt{ }$ \\
\hline J2C & & & $\sqrt{ }$ & P2C & & & $\sqrt{ }$ \\
\hline
\end{tabular}

\subsection{Cast-in-place}

The concrete formwork was using polyvinyl chloride (PVC) with a diameter of $150 \mathrm{~mm}$ and pre-cut the mould to make it easier in the process of removing the concrete from the PVC. Fig.5 shows the harden concrete in a cylindrical mould. DOE mix design methods were used to measure the exact amount of cement, fine aggregate, coarse aggregate and water in this experiment. Concrete mix design was to achieve a compressive strength of $30 \mathrm{~N} / \mathrm{mm} 2$ in 28 days and the design of slump was between $30 \mathrm{~mm}$ to $60 \mathrm{~mm}$. The volume of concrete cubes was $0.1 \mathrm{~mm} 3$ each and concrete anchor bolts for the sample was $5.3 \mathrm{~mm}^{3}$ each. The curing process has been carried out and the water level was ensured at the same level as the concrete cylinder to prevent corrosion of the anchor bolt as it will affect the performance of the bolt [4].

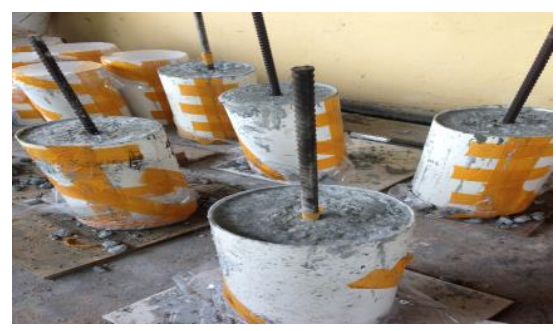

Fig. 5. Bolt embedded in Concrete Cylinder

\subsection{Pull-out test}

Universal Testing Machine has been designed to perform various types of tests or experiments on tensile or compressive experiments or tests. Tests were conducted at Jamilus Research Centre. The sample was placed between the top and bottom and it was attached to the holder at the bottom and the upper parts. First test started with sample J200 and ensured that the jaws must grip tightly for a perfect performance [7]. The machine began to draw a graph of the tensile load until it reached the maximum capacity of the sample. The machine was stopped and the results were recorded in the computer.

\section{Results and Discussions}

The average results for the compression test for 7 days and 28 days were $28.5 \mathrm{Mpa}$ and $30.8 \mathrm{Mpa}$ which has achieved grade 30 as the scope of this research. Pull-out tests were carried out by using the Universal Testing Machine (UTM) to measure the strength of the bond between $J$ and Pigtail in normal concrete. Results data is shown in Table 2 and fig. 6 for pigtail anchor bolt while the bolt anchors $J$ in table 3 and figure 7 . Load was increased gradually to achieve maximum value until failure occurred. Each depth has two samples to get an average value of the maximum tensile load. Based on the average result, $200 \mathrm{~mm}$ embedment reached the lowest maximum value at $37.89 \mathrm{kN}$. The highest average reading was $56.94 \mathrm{kN}$ with a depth of $260 \mathrm{~mm}$. The results showed that the higher the embedment, the higher maximum capacity achieved until failure occurred on the samples. This was because the bond between the anchor bolt and the concrete depended on the surface area or the length of the anchor. The elongation length was also one of the factors in order to achieve maximum value [5]. If the elongation was increased but no load was imposed as seen on bolt anchors P230B, jaws of the universal testing machine (UTM) and rig were loosen during start up. Next, the test was continued with a $4 \mathrm{~mm}$ elongation until maximum tensile load was reached. The value of elongation of 200A and 200B were the highest because of the extension of the original position between the concrete and the anchor has a weak bonding with a depth of $200 \mathrm{~mm}$ and length of anchor bolts the lowest length of $220 \mathrm{~mm}$ [10]. The factors affecting the strength of tensile load were the adhesion concrete to anchor bolts and the friction force between concrete and anchor bolts[20].

Table 2. Result Load Tensile on Pigtail Anchor Bolt.

\begin{tabular}{|l|l|l|l|l|l|}
\hline Sample & $\begin{array}{l}\text { Embedment } \\
(\mathrm{mm})\end{array}$ & $\begin{array}{l}\text { Length } \\
\text { of } \\
\text { anchor } \\
\text { bolt } \\
(\mathrm{mm})\end{array}$ & $\begin{array}{l}\text { Maximum } \\
\text { load }(\mathrm{kN})\end{array}$ & $\begin{array}{l}\text { Average } \\
\text { Maximum } \\
\text { load (kN) }\end{array}$ & $\begin{array}{l}\text { Elongation } \\
(\mathrm{mm})\end{array}$ \\
\hline P1A & 200 & 220 & 28.134 & 37.89 & 14.276 \\
\cline { 1 - 1 } P2A & 200 & 220 & 47.642 & & 14.269 \\
\hline P1B & 230 & 250 & 45.05 & & 5.397 \\
\hline P2B & 230 & 250 & 37.746 & 41.40 & 12.875 \\
\hline P1C & 260 & 280 & 60.529 & & 6.242 \\
\hline P2C & 260 & 280 & 53.628 & 56.94 & 8.239 \\
\hline
\end{tabular}




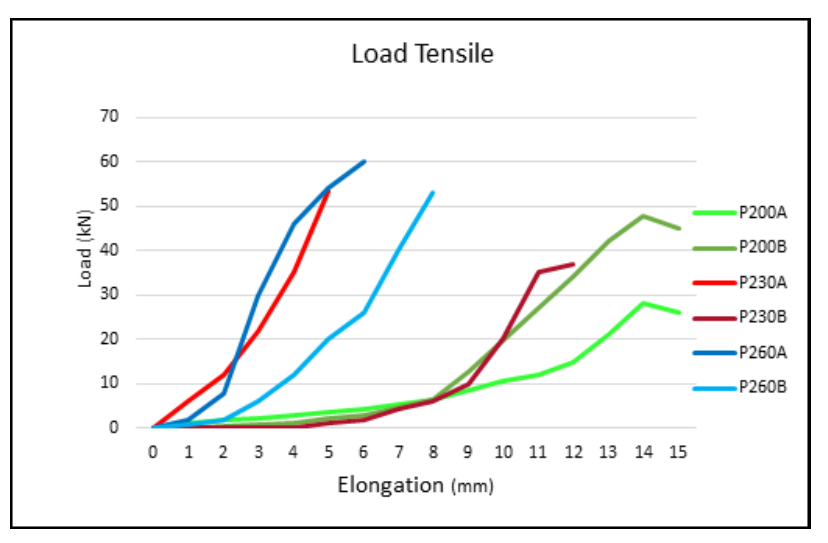

Fig. 6. Pullout test for Pigtail

Sample J2B with an embedment of $230 \mathrm{~mm}$ with $360 \mathrm{~mm}$ length of anchor has the highest maximum tensile load which was $80.642 \mathrm{kN}$ and the lowest maximum value for sample J2A embedment of $200 \mathrm{~mm}$ was $68.12 \mathrm{kN}$. Based on the expected results of embedment depth of $260 \mathrm{~mm}$, which will achieve the highest result, otherwise, the embedment of $230 \mathrm{~mm}$ is the highest maximum tensile load. This was due to the $260 \mathrm{~mm}$ steel failure which occurred and more load was distributed to the steel. Based on Fig.7 it shows that the range of the maximum tensile load does not differ too much. Furthermore, based on the average of the maximum load for each depth of $200 \mathrm{~mm}, 230 \mathrm{~mm}$ and $260 \mathrm{~mm}$ the difference was insignificant and the adhesion and friction forces were almost the same [7]. In conclusion, the average value of the maximum load, the depth of $230 \mathrm{~mm}$ is the optimal depth between $200 \mathrm{~mm}$ and $260 \mathrm{~mm}$ with the use of reinforcement bar Y12 in the concrete cylinder.

Table 3. Result Load Tensile on J Anchor Bolt.

\begin{tabular}{|l|l|l|l|l|l|}
\hline Sample & $\begin{array}{l}\text { Embedment } \\
(\mathrm{mm})\end{array}$ & $\begin{array}{l}\text { Length } \\
(\mathrm{mm})\end{array}$ & $\begin{array}{l}\text { Maximum } \\
\text { load }(\mathrm{kN})\end{array}$ & $\begin{array}{l}\text { Average } \\
\text { maximum } \\
\text { load }\end{array}$ & $\begin{array}{l}\text { Elongation } \\
(\mathrm{mm})\end{array}$ \\
\hline J1A & 200 & 360 & 74.237 & 71.18 & 14.53 \\
\hline J2A & 200 & 360 & 68.124 & & 15.63 \\
\hline J1B & 230 & 390 & 71.761 & & 13.65 \\
\hline J2B & 230 & 390 & 80.462 & 76.11 & 13.50 \\
\hline J1C & 260 & 420 & 74.557 & & 21.56 \\
\hline J2C & 260 & 420 & 76.332 & 75.45 & 27.00 \\
\hline
\end{tabular}

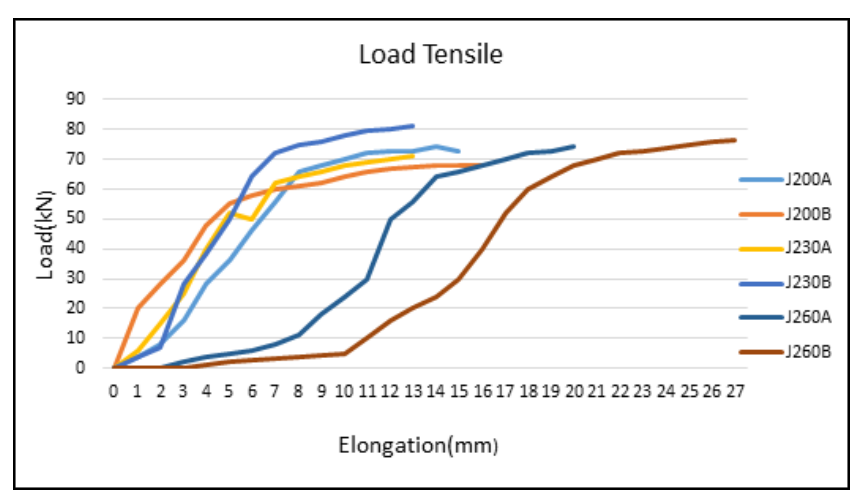

Fig. 7. Pullout test for J
Table 4. Comparison Pigtail with J Anchor Bolt

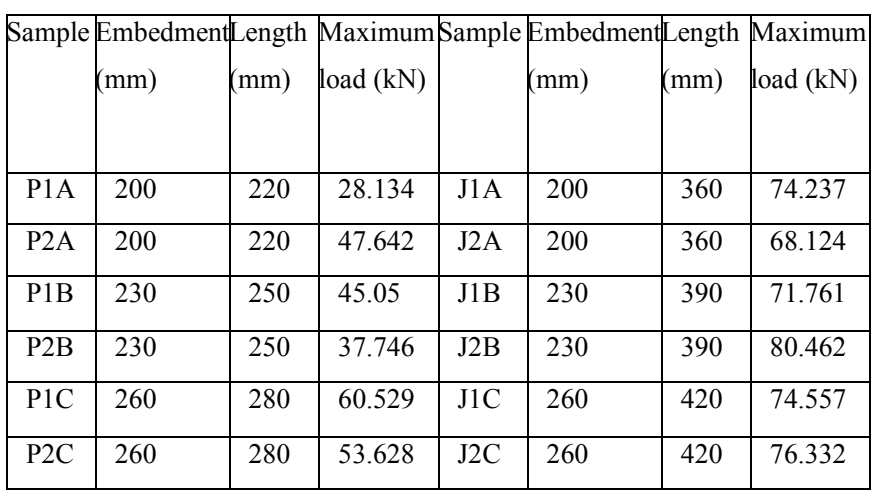

Table 4 shows the comparison between Pigtail and $\mathrm{J}$ anchor bolts. The difference of the maximum tensile load for an embedment of $200 \mathrm{~mm}$ and $230 \mathrm{~mm}$ for each type of anchor bolt that is very significant to $200 \mathrm{~mm}$ pigtail anchor bolt are $28.134 \mathrm{kN}$ and $47.642 \mathrm{kN}$, while the $\mathrm{J}$ are $74.237 \mathrm{kN}$ and $68.124 \mathrm{kN}$. Embedment of $230 \mathrm{~mm}$ anchor bolts for pigtail are $45.05 \mathrm{kN}$ and $37.746 \mathrm{kN}$, while the $\mathrm{J}$ about $71.761 \mathrm{kN}$ and $80.462 \mathrm{kN}$. These results indicated that anchor bolt $J$ is better than the Pigtail because the design of the hook of $J$ anchor bolt increases the ability of cling in the concrete[19]. Furthermore, the friction force is also increased because the length of the anchor bolt embedment in $\mathrm{J}$ is more than in the Pigtail.

Embedment of $260 \mathrm{~mm}$ for Pigtail was almost the same with J, maximum load for Pigtail were $60.529 \mathrm{kN}$ and $53.628 \mathrm{kN}$. Anchor bolts $\mathrm{J}$ maximum tensile load were $75.557 \mathrm{kN}$ and $76.332 \mathrm{kN}$. This was because the highest friction and the highest bonding of the anchor bolt with J260 was $420 \mathrm{~mm}$ length of the anchor [2]. The difference was not too far vary from the embedment of $200 \mathrm{~mm}$ and $230 \mathrm{~mm}$. Each performance indicated the ability of each anchor bolt according to the type and embedment.

Results of this study can be divided into three types. Fig 8 shows the failures that occurred. Steel failure happened to anchor bolt J2A, J1B, J2B, J1C, J2C. It shows all the samples of type $\mathrm{J}$, a strong bond in the concrete due to cracks or failure did not occur in this sample. This was because the load distribution was focused on the steel until failure occurred. Failure blowout occurred on sample P1A, J1A, P1C, P2C. The failure occurred because the dimensions were limited and load distribution were also focused on the tip of the anchor bolt interiors or the end of the anchor bolt cracks begin to occur on the concrete samples. Finally, splitting failure occurred in sample $\mathrm{P} 2 \mathrm{~A}, \mathrm{P} 1 \mathrm{~B}$ and $\mathrm{P} 2 \mathrm{~B}$ also because the end of anchor bolt was positioned close to the edge of the concrete and showed the load spread evenly until failure occurred in the axis indicating the failure was torn in two. Fig 8 shows the common failure in this research. 


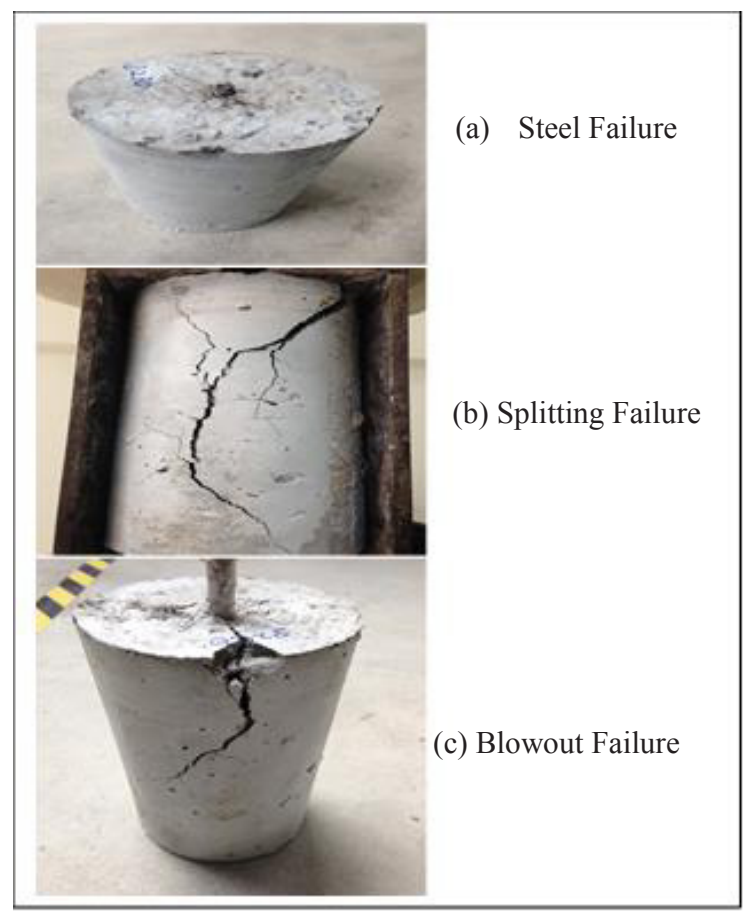

Fig. 8. Types of failure

\section{Conclusions}

$\mathrm{J}$ anchor bolt is widely used in the industry for connecting the structures as precast structure or industrial building system. It is very difficult to be installed in a confined space and needed so much of a skilled labour. Pigtail is a new design but lack of research for this type of anchor bolt design. This research has been done to compare the maximum tensile load, optimum embedment and types of failure for both type of bolts.

It can be concluded, the larger the surface area, the higher maximum tensile load achieved. Friction force was increased between concrete and anchor. Effect from the result for sample P230 was the holder or grip of UTM was loosen and load did not work until elongation reached $4 \mathrm{~mm}$. Every test for the next research is to ensure the grip is tight and replace with a new grip to show perfect result.

Recommendation from this research is to increase the bending of Pigtail to get hook ability to increase maximum tensile load. Besides, increasing the area or volume of samples to get cone failure and adding new design to compare both of these performances.

The author would like to give sincere appreciation to Office for Research, Innovation, Commercialization and Consultancy Management (ORICC) for the supports especially on giving the budget for fee and guidelines given throughout the duration for this project.

\section{References}

1. American Building Institution, Building Code Requirement for Structural Concrete (ACI 318-11). Farmington Hills: ACI 318-11 (2011)

2. Cao Chen, Jan Nemcik, Ren Ting, \& Naj Aziz, International Journal of Mining Science and Technology,23(1) pp. 79-88 (2013)

3. Chanakya A, Design of Structural Elements: Concrete, Steelwork, Masonry, and Timber Designs to British Standards and Eurocodes. Third Edition. New York: Taylot \& Francis,87(2009), pp. 1069 1064. .(2009)

4. Chuka, Chinwko Emmanuel, Odio.B.O Chukwuneke J. L Sinebe J. E, Investigation Of The Effect Of Corrosion On Mild Steel In Five Different Environments, International of journal scientific and technology research vol.3 ( issue 7. )pp. 306-310 (2014)

5. D. A. Winful, K.A. Cashell, A. M. Barnes \& R. J. Pargeter, High Strength Steel in Fire (2015)

6. Eligehausen, R., Mallee, R. and Silva, J Anchorage in Concrete Construction, Ernst \& Sohn: A Wiley Company (2006)

7. Glenn P.Peterson, Pullout testing of cast-inplace.Brigham Young University:Master,thesis. (1998)

8. John G. Shipp And Edward R. Haninger, Design of Headed Anchor Bolts. Engineering Journal, 20(2), pp. 58-69 (1983)

9. Konstantinos Daniel Tsavdaridis, Mohamed A. Shaheen b, Charalampos Baniotopoulos c \& EmadSalem, Analytical approach of anchor rod stiffness and steel base plate calculation under tension, 6, pp. 207-218. (2016)

10. Maria Teresa Gomes Barbosa \& Souza Sánchez Filho. Investigation of Bond Stress in Pull Out Specimens with High Strength Concrete...Journal of Researches in Engineering Civil And Structural Engineering, 13(3), pp. 55-64. (2013)

11. Marko Pavlović, Zlatko Marković, Milan Veljković \& Dragan Buđevac Paredis, J. Bolted shear connectors vs. headed studs behaviour in push-out test Constructional Steel Research, 88,pp. 134-149 (2013)

12. Muhammad Saleem \& Tatsuya Tsubaki, Two-Layer Model For Pull-Out Behav- Ior Of Post-Installed Anchor, Journal of Japan and Society,8(1) pp. 49-62 (2012)

13. Razaqpur A.G., S. Foo, A. Mostafa and M. Saatcioglu, Sesimic Respose Of Three Types Of Post-Installed Anchors In, World Conference on Earthquake Engineering (2008).

14. Robert H. Lesage (Ed.) Cast-in-place and drop-in anchor. Washington D.C: The Aberdeen Group (1971) 
15. R.W.Cannon , D.A. Godfrey, F. L Moreadith, Guide To The Design Of Anchor Bolt and Other Steel Embedments. Concrete International. (1981)

16. S. A. Al- Ta'an \& A. A. Mohammed, Tensile Strength of Short Headed Anchors Embedded in Steel Fibrous Concrete. Civil engineering, Iraq. pp 35-49 (2009)

17. Sato Hiroshi, Kazunori fujikake \& Sidney mindess, Study On Dynamic Pullout Strength Of Anchors Based On Failure Modes.13th World Conference on Earthquake Engineering(854) (2004)

18. Seira Owa, Yasutoshi Yamamoto, Tatsuya Kondo \& Christian Fogstad, Study on Strength and Ductility of Post-installed Adhesive Anchoring System. 15WCEE / 15th World Conference on Earthquake Engineering, Lisbon (2012)

19. Sheikh Abdul Muhaimin, Anchor Bolt Position In Base Plate In Term Of "T" and "J" Anchor Bolt.University Tun Hussien Onn Malaysia:Degree.Thesis (2016)

20. X. Fu and D.D.L. Chung, Sensitivity Of The Bond Strength To The Structure Of The Interface Between Reinforcement And Cement, And The Variability of This Structure. Cement and Concrete Research, 28(6), pp. 787-793, (1998)

21. Williams Form Engineering, Cast-in-Place Concrete Anchors. Portland: Pigtail anchor bolt (2011)

22. Wooyoung Jung, Minho Kwon, Kim Jinsup, and Buseog Ju. Performance E valuation of the PostInstalled Anchor for Sign Structure, Construction and Building Materials, 40 (12), pp. 496-506. (2013) 